\title{
narrativas sobre o Brasil alemão ou a Alemanha brasileira: efnicidade e alteridade por meio da literatura de viagem
}

Sílvio Marcus de Souza Correa*

Resumo. O escopo deste artigo é apresentar uma análise intertextual sobre a etnicidade e a alteridade no Brasil meridional durante o século XIX por meio dos relatos de alguns viajantes alemães. A partir de três viajantes, protótipos de "homens-fronteira", seus relatos serão tratados como operadores discursivos e esquemas narrativos. Trata-se da viagem como experiência cognitiva para uma heterologia, bem como para uma etnicidade "alemã" no Brasil alemão ou na Alemanha brasileira.

Palavras-chave: Etnicidade. Alteridade. Heterologia. Fronteiras.

Os relatos de viajantes alemães sobre o Brasil do século XIX constituem uma fonte ímpar para o estudo de uma etnicidade

* Professor da Universidade de Santa Cruz do Sul (UNISC). Ph D pela Westfälische Wilhelms-Universität Münster.

Anos 90, Porto Alegre, v. 12, n. 21/22, p.227-269, jan./dez. 2005 
Narrativas sobre o Brasil alemão ou a Alemanha brasileira...

alemã no além-mar. Por meio do olhar dos viajantes, pode-se igualmente perscrutar alteridades, especialmente aquela do teutobrasileiro, ou seja, do Mesmo que também é Outro. Enquanto "homens-fronteira", três viajantes alemães servirão de guias a este estudo cujo itinerário tem como ponto principal uma incursão pela alteridade em termos étnicos. ${ }^{1}$

Em situações que engendram incertezas intelectuais, os viajantes experimentam, em geral, uma sensação de estranhamento. Para Freud, o estranhamento pode ser uma sensação frente ao secretamente familiar, posteriormente reprimido, que se encontra, às vezes, explícito no Outro (Freud, 2000). Assim, tem-se um sentimento ambíguo que todos os viajantes alemães manifestaram quando se encontraram em áreas de colonização e imigração alemã, as quais foram vistas como idênticas porque parecem semelhantes, iguais. A partir dessa identificação, tem-se o fenômeno do "duplo".

Essas áreas de colonização e imigração alemã no Brasil meridional serviram aos relatos de viajantes que - com a propaganda de imigração - corroboraram na exportação de uma imagem da América enquanto fronteira em expansão, ou seja, de accomplissement et déroulement da história européia. Porém, como história redimida, como a grande possibilidade de - em terras americanas - passar a limpo o rascunho da história européia. Nesse sentido, rumar para o poente, para uma fronteira ocidental sempre em expansão significava mais do que uma simples forma de fuga ou resistência à influência européia tal como interpretou Frederick J. Turner (1921) em seu clássico The Frontier in American History. Tratava-se, para os imigrantes europeus no extremo sul do Brasil, de uma continuidade da história européia.

O olhar dos viajantes alemães sobre as relações interétnicas no Brasil meridional não deixa de esquadrinhar o outro com seu próprio esquadro. Trata-se, porém, de um olhar distinto daquele já típico aos gregos, a partir do qual Emmanuel Levinas (1972, p.43)

Anos 90, Porto Alegre, v. 12, n. 21/22, p.227-269, jan./dez. 2005 
comparou a viagem de Ulisses à própria imagem da filosofia ocidental. Se a aventura de Ulisses "não foi mais que um retorno à sua ilha natal - complacência do Mesmo, desconhecimento do Outro", os viajantes alemães percorreram o Brasil meridional sem necessariamente se apressarem para retornar e, durante sua estada no estrangeiro, não tiveram sempre complacência dos seus pares e tampouco permaneceram na ignorância do Outro.

Outras duas características que distinguem os viajantes alemães daqueles viajantes da Grécia antiga são o conhecimento da língua estrangeira e a observação participativa. Arnaldo Momigliano (1989, p.513) afirmou que os gregos eram "altivamente monolíngües", afinal, "conversar com indígenas, na língua dos indígenas, não era coisa para eles".

Se Heródoto e outros historiadores gregos registraram os feitos dos "bárbaros" sem contudo saber suas línguas, os viajantes alemães sabiam que sem o domínio da língua portuguesa não era possível qualquer observação participativa no Brasil. Nisso se diferenciavam dos gregos que, para John Redfield (1985, p.101), eram "grandes turistas, mas a observação participativa não lhes interessava".

\section{Da literatura de viagem: viajar para (re)conhecer}

Coadunar a viagem ao saber remonta a experiências arcaicas dos gregos em relação ao seu Mundo Antigo (Hartog, 2004, p.15). Quanto ao Novo Mundo, Marc Lescarbot (apud Hartog, 1999, p.276) expôs seu intento em viajar ao Canadá: "reconhecer a terra de modo ocular". Assim, o que se escreveu nos primeiros séculos da modernidade sobre o Novo Mundo foi o que, em grande parte, se viu com os próprios olhos. Também se escreveu sobre o que se ouviu de terceiros, geralmente de quem viu e mereceu o crédito do narrador. Além do ver, tem-se um complemento à narração por 
Narrativas sobre o Brasil alemão ou a Alemanha brasileira...

meio do ouvir. Para François Hartog (1999, p.281), ouvir significa "ter se informado, investigado junto de pessoas que dizem, por terem elas próprias visto ou por terem ouvido de outros que viram ou que dizem ter visto etc...".

Mas o viajante, que viu e ouviu ou se informou com quem viu, provou de manjares exóticos, expôs seu corpo às intempéries dos trópicos e correu risco de vida, deve ainda assegurar ao leitor que sua narrativa é verossímil?

$\mathrm{Na}$ literatura dos viajantes alemães, a probidade e as limitações de suas narrativas são sempre tratadas nas primeiras páginas. Alguns fizeram epígrafes juramentais como Friedrich von Weech ao escrever Ego verum amo, verum volo dici. Outros, como Robert Avé-Lallemant, destacaram não pretender ocupar "a posição e o mérito de um naturalista profissional". Já a edição em português do livro póstumo do viajante Maximiliano Beschoren foi intitulada Impressões de Viagem.

Os relatos de viagem em língua alemã raramente empregam o termo História (Geschichte), comum entre os títulos dos viajantes franceses. Isso não significa que a literatura de viagem em língua alemã não tenha seus capítulos de história. Mas, como atentou Hartog, essa preeminência atribuída à autópsia em toda forma de investigação tem conseqüências para a história propriamente dita (Hartog, 1999, p.277). Como em Tucídides, aliás, historiador que prefere ver e ouvir a recorrer aos documentos, a história contemporânea torna-se a única forma de história factível possível (Momigliano, 2004, p.68).

Recorrer à narrativa daqueles viajantes que viram e coletaram farto material comprobatório do que escreveram exige, antes de tudo, submeter os enunciados a uma crítica hermenêutica. Afinal, deve-se perscrutar o olhar dos viajantes que, tal como quer fazer crer a narrativa, se apresenta objetivamente descritivo (Hartog, 1999, p.276). 
Miriam L. Moreira Leite ressaltou a vantagem do viajante enquanto "observador alerta e privilegiado do grupo visitado" por ser alguém "de fora" e estar ali "de passagem", sem intenção de ser aceito pelo grupo e com o objetivo de relatar o que conseguiu perceber a seus conterrâneos. Por outro lado, "o viajante traz a postura do civilizado diante do povo atrasado reforçada por uma série de obstáculos lingüísticos, culturais e econômicos à compreensão do grupo visitado" (Leite, 1997, p.10).

Para uma análise intertextual do "olhar dos viajantes" sobre

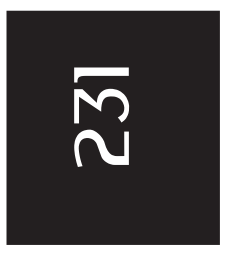
a etnicidade e a alteridade no Brasil meridional durante o século XIX foram escolhidos os relatos de três viajantes alemães. O esquema narrativo composto por três relatos de viagem apresenta uma estrutura formatada aos leitores alemães e algumas características da retórica da alteridade que Hartog apontou para o caso grego. São elas: diferença e inversão, comparação e analogia, a medida de thôma e a obliteração de terceiros pela dicotomia Nós/ Eles. Um outro aspecto presente nas narrativas dos viajantes é o binômio heimlich/unheimlich que será tratado mais adiante.

Esses recursos da retórica da alteridade visam a aproximar e fazer visível, portanto cognoscível, o até então distante e invisível outro. "Uma retórica da alteridade é, no fundo, uma operação de tradução: visa a transportar o outro ao mesmo - constituindo, portanto, uma espécie de transportador da diferença." (Hartog, 1999, p.251-252).

Mas entre o narrador e seu destinatário, persiste uma distinção, pois quando o primeiro recorre ao "eu vi", implicitamente quer dizer que o segundo não. Apesar de descrever o que viu para o seu leitor, este terá sempre um conhecimento traduzido e que não pode ser comparável àquele de quem viu. Ao comentar sobre as condições em que realizou sua viagem pelo sul do Brasil, o alemão Avé-Lallemant (1980, p.350) concluiu que "essa mesma vida dura, violenta, cheia de renúncia, é maravilhosamente atraente e oferece aspectos cuja imagem mesmo uma descrição exata não pode reproduzir".

Anos 90, Porto Alegre, v. 12, n. 21/22, p.227-269, jan./dez. 2005 
Narrativas sobre o Brasil alemão ou a Alemanha brasileira...

O conhecimento traduzido é sempre distinto daquele advindo pela experiência. E a experiência do destinatário pode ainda tolher a tradução operada pelo narrador-viajante. Por isso, ao alertar o leitor sobre as condições de privações e adversidades da viagem, os viajantes alemães parecem escrever aos seus destinatários para mostrar-lhes que jamais, por meio da leitura, poderão ter o mesmo conhecimento daqueles que experimentaram com os cinco sentidos aquela realidade exótica. Os viajantes reconhecem a impossibilidade de traduzir a totalidade da sua experiência itinerante, e que a operação discursiva para aproximação do Outro ao Mesmo pode ser tolhida pelas limitações tanto do narrador-viajante quanto dos seus leitores.

No entanto, a publicação original dos relatos dos viajantes alemães confere a suas viagens ao Brasil uma dimensão de imaginário, ou seja, viagem também do Brasil. Distinto do que Hartog (2004, p.18) escreveu sobre a autopsia dos viajantes gregos, podese afirmar que o olhar dos viajantes alemães raramente pôs à distância o familiar. Trata-se de um olhar que, se recorreu ao diferente, em poucos casos logrou um descobrimento do Outro. O olhar dos viajantes alemães deparou-se com o estranho, mas não cessou de buscar o familiar com o fito de retornar para uma Ítaca germânica. Acabaram encontrando-a nas colônias do sul do Brasil onde se certificaram de si, "encontrando de novo" os sinais e traços de uma etnicidade alemã a ser reinventada.

Antes de abordar os aspectos centrais deste estudo (etnicidade, fronteiras e alteridade), cabe uma sucinta apresentação dos três viajantes alemães cujas narrativas formam o corpo documental da análise intertextual. As partes selecionadas dos três relatos de viagem podem ser consideradas fontes primárias, porque elas foram construídas a partir do que os viajantes viram e não do que ouviram dizer. Trata-se, nesses casos, de "situações testemunhadas" (Leite, 1997, p.15). 


\section{Friedrich von Weech: um bárbaro entre os gregos}

Friedrich von Weech chegou ao Brasil em 1823 e partiu quatro anos depois. Em janeiro de 1827 escreveu, durante a viagem de regresso à Alemanha, Brasiliens gegenwärtiger Zustand und ColonialSystem, besonders in Bequg auf Landbau und Handel, zunächst für Auswanderer. Em 1831, foi publicado em Munique seu segundo livro, intitulado Reise über England und Portugal nach Brasilien und Vereiningten Staaten des la Plata-Stromes während den Jahren 1823 bis 1827. Seus livros visavam a informar os imigrantes alemães sobre aspectos da geografia do além-mar (vegetação, clima etc.), de suas gentes e seus costumes. Na introdução do seu primeiro livro, Weech (1992, p.21) declara ter sido movido pelo desejo de

[...] ser útil aos meus conterrâneos dispostos a emigrar e de dar-lhes meios para seu desenvolvimento em terra estranha, e não para multiplicar a numerosa quantidade de descrições sobre o Brasil.

Nota-se que quando Weech regressa à Alemanha em 1827, o Brasil já havia se tornado um dos pontos de destino da imigração européia. Na Alemanha eram muitas as imagens do Brasil e das quais os viajantes alemães tinham em parte autoria.

Embora não tenha visitado a Província de São Pedro do Rio Grande do Sul, Weech esteve na vizinha Cisplatina em 1825. Por isso, sua referência à recém inaugurada Colônia de São Leopoldo é breve. Suas instruções aos colonos alemães são relativas ao Brasil como um todo, mas suas críticas ao malogro da colônia suíça de Nova Friburgo e da experiência colonial do Barão von Langsdorff acusam sua preferência pela incipiente porém já promissora experiência colonial no Rio Grande do Sul.

Sua viagem ao Brasil não tinha, contudo, o intuito de fazer a viagem do Brasil. Sua viagem não provém daquela atitude em

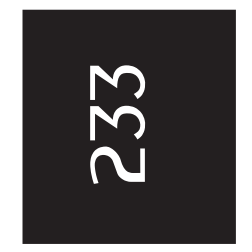


Narrativas sobre o Brasil alemão ou a Alemanha brasileira...

relação ao mundo que Hartog (2004, p.105), no esteio de Heródoto, denomina de theoria: viajar para ver. Sua viagem tinha interesse venal. Uma vez frustrado o sonho de enriquecer-se na América, Weech resolveu relatar aos seus conterrâneos aquilo que viu em sua viagem. É somente a partir do seu regresso que a viagem foi jungida à sophia.

Weech estava convicto de que a história americana seria um desdobramento da história européia. $\mathrm{Na}$ introdução de seu segundo livro, ele expressa a sua preocupação com o crescimento populacional europeu e com a sua conseqüente emigração. Enquanto a Alemanha exportava seus filhos para a Übersee, alguns deles importavam - a partir do relato de suas viagens - imagens de terras exóticas.

O continente americano como fronteira em expansão da Europa parecia, portanto, a confirmação da filosofia da história de Hegel. Desde os tempos da Grécia antiga, um centro cada vez mais expandido para seus confins. Mas, após a guerra russo-turca (1828-29) e o assassinato de Kapodistrias, a Grécia foi submetida a uma monarquia de reinado alemão. Em 1832, Friedrich von Weech recebeu um convite para acompanhar Otto da Baviera a Atenas, onde o príncipe alemão foi coroado rei da Grécia. Friedrich von Weech faleceu na capital grega em 1837. Quatro anos no Brasil e cinco na Grécia foram experiências de um mesmo arquétipo que não deixa de ser paradoxal; afinal, Friedrich von Weech viveu no Brasil como um grego entre os bárbaros e morreu como um bárbaro entre os gregos.

\section{Avé-Lallemant: viajante do Velho e do Novo Mundo}

Robert Avé-Lallemant nasceu (1812) e morreu (1884) em Lübeck e fez seus estudos em Berlim, Paris e Kiel, onde se doutorou em 1837. Antes de viajar para o Brasil, para onde veio exercer 
a medicina, viajou por vários países europeus e pelo Egito. Suas viagens tiveram um caráter apolônico, pois como observou Hartog, Apolônio partiu para medir as sabedorias do mundo e medir-se com elas; em suma, deu muito mais lições que recebeu, ou seja, "viajou decerto para aprender, mas também, senão sobretudo, para exibir marcas de seu próprio saber" (Hartog, 2004, p.224).

Ao contrário de Ulisses, viajante a contragosto, AvéLallemant retornou à Europa depois de 17 anos no Brasil; porém, não volveu à sua Ítaca. Em 1855, partiu de Trieste para empreen-

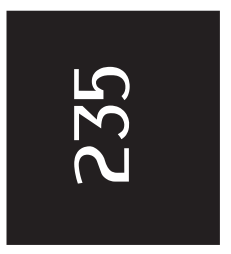
der a circunavegação do mundo a bordo de uma fragata austríaca. Vicissitudes durante o périplo o fizeram aportar novamente no Rio de Janeiro, de onde partiu para suas viagens terrestres pelo norte e sul do país, cujos relatos foram publicados em Leipzig respectivamente sob os títulos de Reise durch Süd-Brasilien (1858) e Reise durch Nord-Brasilien (1859). Sobre o Egito, foi publicado em 1872 sua Fata Morgana.

Aspecto particular de Robert Avé-Lallemant enquanto "homem-fronteira" é seu fascínio tanto pelo Mundo Antigo quanto pelo Mundo Novo. Seu deslocamento físico pelo mundo talvez lhe fomentasse a ilusão de uma unidade temporal entre passado, presente e futuro. Se ele estava imbuído do ideal do Grand Tour enquanto viagem por prazer e por amor à cultura antiga tal como empreenderam no século XVIII o novelista britânico Thobias Smollet, o poeta alemão Johann W. von Goethe e o antiquário inglês Richard Payne Knight (cf. Salgueiro, 2002); ele também estava fascinado pelo novo mundo e disposto a seguir a moda dos naturalistas alemães e franceses como Alexander von Humboldt e Aimé Bonpland.

Se sua primeira viagem ao Brasil teve um caráter predominantemente profissional e serviu mais para ensinar do que para apreender. A partir de seu retorno ao Brasil em 1855, sua viagem pela hinterlândia foi eminentemente de um turista interessado em se informar e, para isso, se valeu do "ver". Sobre a Colônia alemã 
Narrativas sobre o Brasil alemão ou a Alemanha brasileira...

de São Leopoldo, Avé-Lallemant (1980, p.377) declarou que “antes que eu lá estivesse, as minhas próprias idéias eram puerilmente pequenas". Além de ver, o viajante alemão valeu-se, sobretudo, da interação verbal com os brasileiros de variadas origens. "Em minha peregrinação estive em contato com todos esses elementos e entendi-me perfeitamente com todos eles." (ibid., p.375). É o próprio Avé-Lallemant quem aconselha: "Viaje a cavalo nas picadas desta nova Alemanha, ouça e veja e, sobretudo, fale com o povo da serra e, pelo menos por alguns momentos, viva com ele, inteiramente à sua maneira, para que ele não se acanhe, nem se intimide." (ibid., p.126).

Porém, o viajante alemão não tem muita abertura para a cultura alheia e tampouco opera um relativismo entre a sua sabedoria e aquela dos "bárbaros", como demonstrou Momigliano para o caso dos gregos. O viajante alemão está longe do filósofo cínico, Diógenes de Sínope, que fez "o elogio da vida selvagem e pretendeu subverter o centro da cidade ou da grecidade pelas margens, demonstrando que os verdadeiros civilizados não são os que se crêem como tais" (Hartog, 2004, p.21).

Como o seu compatriota Friedrich von Weech, Avé-Lallemant (1980, p.385) estava convicto de que o Rio Grande do Sul seria o desdobramento da história européia. "Assim não podemos deixar de confessar que encontramos no Rio Grande uma terra maravilhosa, como dificilmente se acha uma segunda capaz, e chamada a um desenvolvimento material e espiritual segundo as normas européias". Para ele, a germanização do Brasil meridional significa o espraiar da civilização sobre a barbárie, um continuum entre o Antigo e o Novo Mundo.

\section{Beschoren: um prussiano nas selvas do Rio Grande}

Nascido em 1847 em Sachsen, Província prussiana, Maxiliano Beschoren estudou Engenharia e Matemática em Dresden e con-

Anos 90, Porto Alegre, v. 12, n. 21/22, p.227-269, jan./dez. 2005 
cluiu seus estudos em Halle. Com vinte anos incompletos, aventurou-se para o Brasil, especificamente a Província de São Pedro do Rio Grande do Sul. Inicialmente, foi professor em Porto Alegre, mas logo surgiu a oportunidade para trabalhar como agrimensor, profissão que exerceu durante 18 anos até sua trágica morte em 1887. Sobre sua morte, ainda pairam dúvidas. Devido ao seu serviço de agrimensura é muito provável que indígenas desconfiassem de um projeto colonizador em Nonoai, aliás, local de sua morte e de uma reserva indígena. A tensão era grande nessa re-

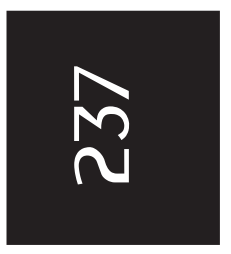
gião, e Beschoren fez referência em seu diário sobre inamistosos contatos com indígenas.

O livro póstumo intitulado Beiträge zur nähern Kenntnis der brasilianischen Provinz. São Pedro do Rio Grande do Sul. Reisen und Beobachtungen während der Jahre 1875-1887 foi publicado em Berlim em 1889. Em vida, Beschoren havia contribuído como articulista em revistas alemãs como a Export e durante anos em periódicos teuto-brasileiros como a Deutsche Zeitung e Von Kosertiz Zeitung. Em uma carta de 8 de julho de 1886, Beschoren referiu-se ao livro que estava escrevendo e aos manuscritos enviados para a Alemanha. Max Beschoren direcionou seus escritos para aquilo que os alemães chamam de Erdkunde. O destinatário do seu livro era, portanto, o leitor alemão, notadamente geógrafos e "amigos da geografia”, como indicou Henri Lange no prefácio da obra.

A estrutura narrativa da obra, mesmo que postumamente alterada em sua forma, segue a lógica dos relatos de viagem em que a veracidade da narração está assegurada pela condição de viajante do autor, aquele que escreve o que vê. Assim, o subtítulo da obra (Reisen und Beobachtungen) acusa já uma noção de que as viagens se desdobram em observações. Talvez pela sua profissão, Beschoren foi um viajante que tentou literalmente mensurar seus conhecimentos, e a viagem foi sua forma dileta. 
Narrativas sobre o Brasil alemão ou a Alemanha brasileira...

\section{Etnicidade e "homens-fronteiras"}

Para a formação de uma identidade étnica, a sua aceitabilidade pelos insiders e a inteligibilidade da mesma para os outsiders são aspectos imprescindíveis. No caso dos imigrantes alemães e seus descendentes, os relatos de viagem permitem inferir que as identidades regionais dos imigrantes foram sendo negociadas e resultaram - por meio das interações intra e intergrupais - na formação de uma etnicidade alemã no Brasil.

A narrativa dos viajantes acusa, no entanto, certos 'resíduos' das identidades regionais dos imigrantes alemães. Em seu diário de bordo, Avé-Lallemant (1980, p.240) ficou comovido ao encontrar um conterrâneo seu com quem falou no "rude dialeto do Mecklenburg", em plena região das Missões. Já em Santa Maria, Avé-Lallemant observou que "até o dialeto do Palatinado se fala aqui nas ruas, como língua do país, e, como lá, se ouve em toda parte. No entanto, no 'palatinatismo' se intromete a originalidade da vida sul-rio-grandense" (ibid., p.214).

O hibridismo cultural foi referido em outra passagem. Em uma casa "perfeitamente alemã", Avé-Lallemant (1980, p.191) encontrou "traço de gaucharia". Tratava-se da qualidade de ginete de um dos filhos do seu hospedeiro. "O rapazote era dos pés à cabeça um gaúcho, um centauro!”.

Esses exemplos de uma mudança cultural nos hábitos e costumes do grupo étnico alemão não significam que as fronteiras entre os grupos tenham sido abolidas. Afinal, um grupo pode adotar elementos culturais de um outro grupo, como a língua, a forma de moradia ou costumes alimentares, e continuar mesmo assim a ser percebido e a perceber-se como diferente. Ou seja, a manutenção das fronteiras entre os grupos étnicos não depende da permanência de suas culturas. A identidade étnica da fase pioneira da colonização acusa, ao mesmo tempo, a persistência de fronteiras 
entre "alemães" e os outros e a mudança cultural operada no ingroup dos imigrantes e seus descendentes.

Se a etnicidade alemã com a qual se deparam os viajantes ao longo do século XIX incorpora elementos brasileiros como a vestimenta e hábitos alimentares, ela apresenta alguns 'traços' regionais da cultura alemã que são indistinguíveis aos membros do out-group. Muitas das clivagens internas do in-group alemão não interferiram na exodefinição da etnicidade alemã. No entanto, a exodefinição interfere no modo como um grupo étnico se define.

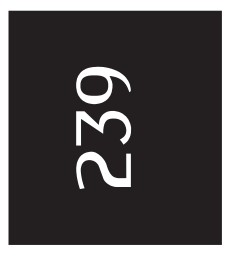

Para Wallerstein (1960), a pertença a um grupo étnico traduz uma interação entre a auto-definição dos membros de um grupo e a definição dos outros grupos. Já Drummond (1981) acentua a atribuição categorial da identidade étnica, que é sempre e inevitavelmente um produto de atos significativos de outros grupos. Poutignat e Streiff-Fenart (1998) corroboram a afirmação de que a identidade étnica nunca se define de maneira puramente endógena pela transmissão de uma suposta essência e de qualidades étnicas. A etnicidade é um processo dinâmico sempre sujeito a redefinição e recomposição.

Esse dinamismo da etnicidade alemã não foi percebido por Friedrich von Weech (1992, p.110), talvez, porque sua viagem pelo Brasil coincidiu com a fase inicial da colonização. Para o viajante, o imigrante difere pela sua experiência pretérita do brasileiro que "desconhece as comodidades de um país civilizado" e, por isso, "indiferente a tudo o que o cerca, suporta-o sem se sentir insatisfeito".

Weech (1992, p.110) considerou a vida do colono árdua, "extremamente monótona, uma constante luta contra privações de todo tipo". Por isso, não aconselhava para "aquele que tiver morado constantemente na cidade, estiver acostumado à vida mundana e tiver sido educado para ela" imigrar para o Brasil. Para o viajante alemão, a vida nas colônias era para genuínos camponeses. "Aquele que na Europa tiver vivido apenas no campo se adaptará melhor a esse tipo de vida." 
Narrativas sobre o Brasil alemão ou a Alemanha brasileira...

Além da relação assimétrica entre o bárbaro e o civilizado, nota-se que nos conselhos de Weech há uma distinção entre o agrícola e o urbanita. O olhar urbano de Weech faz do colono alemão um agrô̂kos, que exprime também "uma maneira de ser: camponês, rústico, grosseiro" (Hartog, 2004, p.138). Mas as colônias alemãs durante muito tempo fizeram dos seus núcleos urbanos meros apêndices do seu entorno agrícola. Elas se aproximavam daquilo que Platão idealizou, ou seja, uma polis "onde não houvesse a necessária ruptura entre cidade e campo" (ibid., p.142).

Os colonos eram como "homens-fronteira" que, ao adentrar as matas, se tornam eles próprios marcos de fronteira. É no lugar desbravado por esses "homens-fronteiras" que se edifica a cidade, que se ampara dos campos cultivados onde o agricultor ?se torna por extensão um cidadão. São eles forasteiros, gentes do exterior que se interiorizam no além-mar, ampliando assim a comunidade (oikouméne) germânica.

"Homens-fronteira", eles delineiam, assim como os viajantes alemães, os contornos de uma identidade alemã. Suas gestas alimentam as narrativas dos viajantes que, vindas de alhures, são lidas por alemães que ficaram do outro lado do oceano. Embora estilhaçada, a tradição cultural desses "homens-fronteira" transmigra parcialmente ao Novo Mundo onde, em muitos casos, encontra um verdadeiro exílio. Avé-Lallemant (1980, p.317) chega a comentar sobre certas manifestações culturais reprimidas na Alemanha e com as quais se depara no Brasil meridional.

Já Beschoren (1989, p.125-126) encontrou na fronteira com a Argentina um compatriota alemão, morador antigo da região, que lhe serviu de point de repère. "Realmente me fez um grande bem, encontrar aqui, um pedaço da cultura européia, parecendo que, com a travessia do rio, de repente, tivesse dado um passo para mais perto da civilização." Mesma sensação teve Avé-Lallemant (1980, p.240) ao encontrar um conterrâneo seu em plena região das Missões, onde ele acreditava que "todo o europeísmo tinha acabado".

Anos 90, Porto Alegre, v. 12, n. 21/22, p.227-269, jan./dez. 2005 
A Heimweh dos viajantes alemães pode ser percebida também quando o seu olhar vê o que não está ali e lhes permite assim fazer analogias das paisagens por onde passam com paisagens da Alemanha. A analogia provoca um sentimento ambíguo; afinal, trata-se de uma presença virtual, daquilo que está tão longe, mas tão perto. Algumas situações, especialmente de solidão, os transportam para longe. Essa viagem de retorno pode ser tanto espacial como temporal. No caso de Beschoren, sua saudade o transporta não só de volta para a Pátria, mas também para um passado juve-

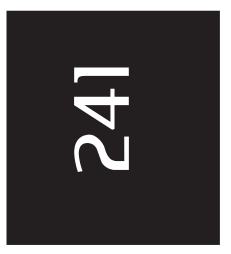
nil.

Justamente em noites tão infinitas e solitárias surge a lembrança de imagens do passado, de uma juventude bela e feliz. Em noites assim, sozinho, na selva silenciosa, desperta a saudade da pátria, com grande intensidade. As recordações nos levam pelas terras e mares em direção à pátria, e ao distante e querido lar paterno. (Beschoren, 1986, p.102).

Entre os viajantes alemães, Avé-Lallemant talvez seja aquele que mais fez analogias entre as paisagens do Rio Grande do Sul e da Alemanha. Dos rios que imitam o Reno e dos campos que se assemelham aos de Holstein, o viajante alemão busca o familiar para si e para seus leitores.

Quantas vezes me julguei transportado a um lago de Holstein ou a uma pastagem do Meclemburgo, quando eu estava no Guaíba, no Jacuí, no Taquari e mesmo no Uruguai [...]. (Avé-Lallemant, 1980, p.386).

Nesse sentido, o viajante persiste paradoxalmente no seu périplo enquanto "homem-fronteira". Como escreveu Hartog (2004, p.15) sobre a fronteira na Grécia antiga: os viajantes vão para os confins, mas estão dos dois lados da fronteira. As imagens pátrias redescobertas em paisagens exóticas acusam, no entanto, 
Narrativas sobre o Brasil alemão ou a Alemanha brasileira...

que a fronteira deve ser entendida não mais no sentido daquilo que separa as partes, mas que as une (Piccolo, 1999).

\section{Fronteiras diacrônicas do Deutschtum}

Ao tratar dos limites da helenização, Arnaldo Momigliano (1991) demonstrou suas fronteiras porosas e a interação cultural da Grécia com outras civilizações contemporâneas suas como a céltica, a judaica e a persa. Momigliano ressaltou o conhecimento ocidental da civilização persa por meio do grego. Observadas as referências bibliográficas do historiador piemontês, percebe-se que há um predomínio da literatura em língua alemã para a História Antiga, ao menos para o período helenístico, o que significa dizer que há uma Grécia alemã. Tem-se assim uma interação cultural de civilizações extemporâneas perceptível a partir da abordagem que Hartog denomina "história cultural de longa duração" (Hartog, 2004, p.13).

Mas se a historiografia em língua alemã permite uma viagem da Grécia e de Roma, para ela muito contribuiu a filosofia da história do idealismo alemão. Para a afinidade de intelectuais alemães com a Grécia antiga, foi importantíssima a contribuição das viagens à Itália de J. J. Winckelmann, Alexander von Humboldt e J. W. Goethe. A língua alemã é igualmente obrigatória para os estudos sobre a viagem do Brasil para a Alemanha. Desde a literatura quinhentista dos aventureiros Ulrich Schmiedel e Hans Staden, imagens do Brasil viajam para a Alemanha. O Brasil francês de Jean de Léry ou inglês de Robert Southey são, para Oliveira Lima (1912), incomparáveis ao Brasil alemão.

Especificamente sobre o Brasil imperial, Oliveira Lima (1912) afirma que "a história do I Império não poderia ter sido escrita sem a contribuição dos viajantes alemães". Além dessa viagem do Brasil por intermédio dos viajantes, os historiadores alemães e 
teuto-brasileiros contribuíram sob diversas correntes historiográficas para uma outra viagem brasileira pela Alemanha. Tratase da história do Brasil alemão. A colonização e a imigração alemãs no Sul do Brasil, notadamente no Rio Grande do Sul, foram objetos de estudos históricos desde o final do século XIX, e podese afirmar que tanto quanto a alteridade grega, a brasileira influenciou o conhecimento dos alemães sobre os outros, mas também sobre si mesmos. Para os viajantes alemães que percorreram o Brasil meridional, a retórica da alteridade operou no sentido de promover um conhecimento de si mesmo. Avé-Lallemant (1980, p.273) provou de um relativismo radical ao se considerar literalmente um bárbaro quando não entendeu versos em língua guarani. Os demais viajantes também tiveram experiências de alteridade típicas a quem veste a pele de "homem-fronteira".

Da Grécia antiga ao Brasil imperial, o Deutschtum foi reinventado dentro de fronteiras diacrônicas. A etnicidade alemã reclamou raízes indo-européias que a Volkerkunde dos finais do século XIX e início do século XX encontrou facilmente ao seguir o caminho já aberto por Herder, Humboldt e Goethe rumo à Antiguidade clássica.

Para os viajantes alemães, havia um patrimônio cultural comum entre os gregos e os alemães, o que permitiu aos segundos o uso de analogias e citações clássicas que, em alguns casos, tornava familiar aquilo que deveria se estranhar no Novo Mundo. Nas cercanias de São Borja, Avé-Lallemant (1980, p.284-285) descreve seu encontro com o octogenário Fioravanti, um homem de origem grega que lhe disse haver entre eles um "parentesco espiritual." Para o viajante alemão, a conversa entre eles havia entusiasmado o velho grego como Anacreonte em pleno $\theta \varepsilon \lambda_{0} \theta \varepsilon \lambda \mathrm{o}$ $\mu \alpha v \eta v \alpha 1$ !

No retrospecto de sua peregrinação no Rio Grande do Sul, Avé-Lallemant (1980, p.386) descreve seu desejo onírico no qual a Grécia antiga se confunde aos confins do Brasil imperial. 
Narrativas sobre o Brasil alemão ou a Alemanha brasileira...

Muitas vezes me parecia que devia tirar do solo miríades de alemães e transformar as formigas do campo em mirmidões germânicos e com eles começar vigoroso combate contra estes modernos campos de Tróia!

A retórica da alteridade dos viajantes circunscreve a etnografia do Brasil meridional a uma geografia de espaços divididos. Como apontou Frederick Turner, a fronteira na América é "the meeting point between savagery and civilization". Além dessa fronteira com os selvagens, os imigrantes alemães e seus descendentes contribuíram para uma fronteira entre duas paisagens culturais na Província. $^{2}$

Com exceção de Friedrich von Weech, os outros viajantes alemães atentaram para uma divisão espacial da Província do Rio Grande do Sul, notadamente entre a metade sul, predominantemente de campos naturais e propícios ao pastoreio, e a metade norte, região florestal para onde se estendeu a agricultura colonial. $\mathrm{Na}$ primeira, a organização sócio-econômica do espaço era marcada pelo latifúndio escravista enquanto que, na segunda, pelo minifúndio e pelo regime de trabalho familiar nas lavouras.

Cônscios do término da escravidão no país, os viajantes alemães não tinham dúvidas quanto à futura expansão colonial na Província e o predomínio dos colonos alemães. A fronteira interna da Província era igualmente uma fronteira externa, uma fronteira em movimento, uma fronteira "germânica".

Assim vencem, trabalhando, esses pioneiros da disciplina, da laboriosidade e dos costumes alemães, penetrando cada vez mais nas selvas, de elevação em elevação, de vale em vale, de serra em serra, de rio em rio! Muitos deles, muitos milhares já se dispersaram na magnífica bacia do Jacuí e de outros confluentes do longo Guaíba; assim muitos deles já foram para o lado do Uruguai e lá plantaram em regiões isoladas o estandarte do trabalho e da inteligência. O grande e difícil começo está feito, a primeira tentativa foi 
brilhantemente realizada. Não perece a poderosa seiva da raça germânica - grande e forte cooperação para o "surge et ambula”. (Avé-Lallemant, 1980, p.155).

A imagem dos imigrantes como arautos da civilização não era um apanágio dos viajantes alemães. Viajantes franceses, como Arsène Isabelle e Nicolau Dreys, igualmente fizeram elogios à colonização alemã.

Em meados do século XIX, as áreas de colonização alemã

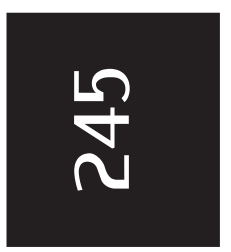
eram vistas como ilhas de civilização no meio de um oceano verde e inculto. Próximo à Colônia alemã de São Leopoldo, Avé-Lallemant (1980, p.122-123) descreveu o seguinte:

Ao sopé de uma alta serra, por causa de dois picos dominantes, chamada Serra dos Dois Irmãos, fica, a uma duas léguas da Vila, o pequeno e bonito núcleo colonial, a Serra de Hamburgo ou Cidade de Hamburgo, com uma igreja no alto e graciosas casas em baixo. Parece o conjunto um viçoso jardim, com espaços livres semelhantes a parques, emoldurados nas matas escuras da serra que aqui começa.

Mesma imagem aparece nas cercanias da Colônia alemã de Santa Cruz.

Só a fumaça, que sobe lentamente de alguns pontos, anuncia que audazes agricultores já se estabeleceram no vale solitário, que do caos da natureza selvagem brotará uma cultura policiada! (ibid., p.172).

Por meio dos relatos dos viajantes, as colônias alemãs aparecem como ilhas de civilização no meio da barbárie ou do caos da natureza selvagem. As colônias alemãs formavam um arquipélago cuja paisagem cultural contrastava com aquela caracterizada pela imensidão das estâncias dos primeiros povoadores luso-brasileiros. O contraste era também demográfico, ou seja, colônias com densa 
Narrativas sobre o Brasil alemão ou a Alemanha brasileira...

população, envoltas por desertos humanos. A divisão espacial do Rio Grande do Sul entre áreas de povoamento antigo (luso-brasileiro) e de colonização alemã também era demarcada pela cultura, notadamente pela língua.

Causa impressão peculiar ao recém chegado que pela primeira vez viaja nessa região, com milhares de habitantes, viajar o dia inteiro sem ouvir falar, pelo caminho, outra língua senão a alemã. (Avé-Lallemant, 1980, p.410).

Em 1827, Friedrich von Weech (1992, p.111) já aconselhava aos seus compatriotas as colônias agrícolas do Rio Grande do Sul, onde o imigrante "poderá viver totalmente de acordo com os costumes europeus". Mas com o aumento do fluxo imigratório e com a expansão das colônias alemãs, o "perigo alemão" era propalado nos discursos dos políticos sul-rio-grandenses, pois, promovida inicialmente pelo Império e levada a cabo pela Província em consórcio com a iniciativa privada, a imigração alemã não logrou um incremento demográfico equânime em termos regionais. Se nos meados do século XIX muitos deputados defenderam a imigração e a colonização européia, outros, como os deputados Miguel de Castro Mascarenhas e João Jacinto de Mendonça, temiam o espectro atávico das "invasões bárbaras" (Piccolo, 1999, p.12).

Nesse contexto de imigração alemã para o Rio Grande do Sul, as línguas portuguesa e alemã serviram como demarcadoras de espaços étnicos. De acordo com o ponto de vista, seja de brasileiros como de alemães, tratava-se de uma divisão espacial entre civilizados e bárbaros, em que bárbaro é sempre o Outro.

A "nacionalização" proposta por João Jacinto de Mendonça, na Assembléia Legislativa - sessão de 26 de outubro de 1852 -, não deixa de ser uma tentativa de "civilizar o bárbaro". 
É necessário ir nacionalizando nos costumes a população que hoje ocupa a Colônia de São Leopoldo, porque é composta de nacionais, e não de alemães, de brasileiros ali nascidos que devem estar sujeitos às mesmas leis que nós estamos, e a respeito dos quais não somos obrigados a respeitar os preconceitos [...] que não pode prever os inconvenientes que resultam de uma população nacional com hábitos propriamente estrangeiros [...] Entendo que o mal é em si muito grave, e que convém remedia-lo [...]. (apud Piccolo, 1999, p.12).

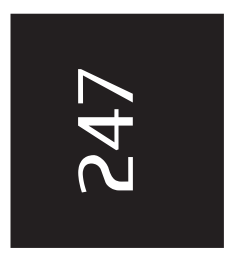

Nota-se que não se quer fazer do teuto-brasileiro um meteco, e sim um igual. A condição de meteco poderia ser auferida para os imigrantes alemães, porém, seus filhos nascidos no Brasil deveriam ser cidadãos plenos. Nesse sentido, o deputado Eudoro Berlink, em seu discurso na sessão de 22 de julho de 1869 da Assembléia Provincial, pondera:

Eu não quero que o colono renegue sua pátria, as tradições de sua terra, nem abandone costumes tradicionais pelos nossos. O que exijo porém, é que os filhos dos colonos, aqueles que nasceram em terra brasileira, sejam brasileiros, sintam com o sentir, com a vida e com o espírito com que sentem e partilham dos direitos comuns os brasileiros da raça portuguesa. (apud Piccolo, 1999, p.15).

Em 1860, a xenofobia, especialmente a aversão luso-brasileira à formação de uma alteridade em áreas de colonização alemã, isto é, do teuto-brasileiro, foi alvo da crítica do historiador alemão Handelmann (1982, p.354), que defendeu uma certa autonomia das colônias alemãs. Handelmann também pleiteava pela equiparação legal da língua alemã com a oficial, a portuguesa. Sua posição não era em prol de um estado no Estado, de uma nova Alemanha no além-mar, mas sim de incrementar os meios institucionais da integração social dos imigrantes no fito de favorecer "a fusão para a unidade da nova raça” (apud Piccolo, 1999, p. 355).

Anos 90, Porto Alegre, v. 12, n. 21/22, p.227-269, jan./dez. 2005 
Narrativas sobre o Brasil alemão ou a Alemanha brasileira...

Tal como Timeu, Handelmann era um historiador de gabinete. Seu interesse pela história das Américas, no entanto, acusa uma percepção acurada de que o sentido da história da humanidade se voltava para o continente americano. Se o siciliano Timeu havia se interessado pela história dos gregos no Ocidente e fez "pelo oeste o que Heródoto havia feito pelo leste" (Momigliano, 1966, p.61), Handelmann escreveu a História dos Estados Unidos da América do Norte e a História da ilha do Haiti (ambas publicadas em Kiel no ano de 1856) e ainda História do Brasil (publicada em Berlim em 1860) sob a influência da filosofia da história de Hegel. Cabe lembrar que Handelmann estudou e viveu toda a sua vida em Kiel, onde lecionava o historiador e especialista do período helenístico, Johann Gustav Droysen. Se a época helenística, para Droysen, desempenhou o papel que, para Hegel, desempenhou Roma na história da humanidade, para Handelmann, por meio da imigração européia, a América representava o cenário da nova etapa da história da humanidade, a fronteira em expansão de uma nova oikouméne.

Comparado aos três continentes do chamado Velho Mundo, inesgotável matriz de povos vibrantes de vitalidade, forma vivo contraste, como se sabe, o Novo Mundo, a América; a sua raça autóctone, a raça índia, em geral, mostra pequena capacidade vital, e já se vai extinguindo em muitos lugares; e, assim como no solo da América foi a imigração estrangeira que veio despertar a vida histórica, assim ela fica sendo contínua necessidade para os seus países, a fim de que a vida histórica e o desenvolvimento espiritual e material prossigam sempre, como até aqui. (Handelmann, 1982, p.339).

Nota-se que o paradigma de Levi-Strauss de sociedades "frias" e "quentes" foi, de certa forma, antecipado por Handelmann, para quem as sociedades indígenas da América "se esfriavam". O mesmo paradigma foi aludido por Hartog (2004, p.95) para a rela-

Anos 90, Porto Alegre, v. 12, n. 21/22, p.227-269, jan./dez. 2005 
ção entre gregos e bárbaros, na qual os primeiros "se esquentavam" enquanto os segundos "esfriavam", permanecendo bárbaros. E se para Tucídides, a "grecidade eleva-se de um fundo de barbárie", pode-se dizer que a germanidade idem e, assim como os gregos, os alemães se pretendiam seminais.

Para Handelmann, a imigração e a colonização européias eram vitais ao continente americano. Uma analogia da importância da imigração para a América com aquela das colônias gregas para a helenização do mundo antigo, principalmente de Roma, não é descabida. Cabe ainda lembrar que se Winckelmann não teve o fito de enquadrar a cultura grega no contexto da História Universal, esta é a preocupação mor de Herder, para quem uma renascença "grega" em solo germânico era possível (Bornheim, 1975, p.24). Herder estava convicto de uma afinidade profunda entre a Grécia antiga e a Alemanha moderna, e nisso teve eminentes seguidores como Humboldt e Goethe. Mas, como advertiu Fustel de Coulanges (1975, p.173),

[...] nem gregos, nem mesmo os romanos, praticaram a colonização nos mesmos moldes do mundo moderno. Uma colônia não era dependência ou anexo do Estado colonizador: era um Estado completo e independente. Todavia, existia entre a colônia e a metrópole um vínculo de natureza particular, e isso provinha do pacto como a colônia fora fundada.

O pleito de Handelmann pela isonomia política entre naturais e imigrantes no Brasil, e pela manutenção da língua alemã, bem como da religião reformada, era uma forma de reivindicação por um vínculo cultural entre as colônias e a Alemanha. Handelmann não via as colônias alemãs no Brasil como anexos da Alemanha, mas desejava um vínculo entre elas. Ele idealizava as colônias alemãs como uma apoikía germânica na América. E se "era mesmo costume antigo entre os gregos que a colônia recebesse da 
Narrativas sobre o Brasil alemão ou a Alemanha brasileira...

metrópole os pontífices que presidiam o seu culto e zelariam pela conservação dos ritos" (Coulanges, 1975, p.174), padres e pastores da Alemanha eram enviados para as colônias alemãs, sendo os luteranos mais tenazes nos cuidados com o Deutschtum im Ausland; enfim, com o vínculo religioso com as colônias do além-mar.

Para Avé-Lallemant (1980 p.386), o Rio Grande do Sul era uma "Alemanha melhorada", o que significava alargar as fronteiras germânicas sobre o Brasil meridional, senão aquelas geopolíticas, as culturais e comerciais. Max Beschoren (1986, p.196) comenta que "o reavivamento da colonização na Província reforçaria a missão de alto nível histórico e cultural, traçada na Nova Pátria, mantendo ao mesmo tempo intercâmbio comercial e cultural com a velha Pátria".

Como não houve uma integração institucionalizada dos imigrantes e seus descendentes durante as primeiras décadas da imigração alemã para o Rio Grande do Sul, predominaram no construto da identidade étnica alguns elementos mais distintivos do in-group como a língua e a aparência física. A religião serviu igualmente para os imigrantes alemães e seus primeiros descendentes se distinguirem dos nativos. No aspecto religioso, cabe salientar que, se o contraste era maior em relação aos protestantes, mesmo o catolicismo alemão diferia do ibérico e, sobremaneira, da religião popular no sul do Brasil.

Último ponto a considerar sobre as fronteiras diacrônicas do Deutschtum concerne à Idade de Ouro que não se encontra num passado, mas sim no porvir e nos confins. Para Aristóteles (apud Hartog, 2004, p.118), a posição geográfica da Grécia era vantajosa por ser intermediária entre a Ásia e a Europa, entre o norte frio (Cítia) e o sul quente (Egito) e permitia aos gregos amalgamar em harmonia as qualidades dos extremos. Para os viajantes alemães, o sul do Brasil era a terra promissora para os imigrantes alemães elevarem uma civilização. Como a Grécia para o Mundo Antigo, Avé-Lallemant (1980, p.383) afirmou que a posição geográfica e 
as condições climatológicas do Rio Grande do Sul eram as melhores para a imigração alemã. Avé-Lallemant (ibid., p.415) previu ainda: "Em particular pertence o próximo século na Província do Rio Grande do Sul, talvez todo o seu futuro aos honrados, probos e vigorosos lavradores imigrados da Alemanha!" Na mesma orientação discursiva, vai a fala do deputado Fidêncio Nepomuceno Prates, em defesa da colonização do Rio Grande do Sul com imigrantes alemães, em sessão dos parlamentares da assembléia legislativa em 27 de novembro de 1854:

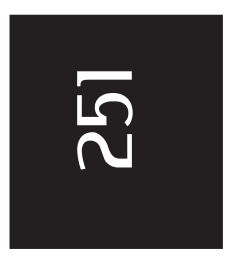

Há períodos na história, em que a força universal da inteligência e vitalidade, que anima as nações, parece retirar-se de umas para concentrar-se em outras: os povos de origem "latina" estão desde século e meio como exaustos e em declínio enquanto que as raças "germânicas" cheias de seiva, de ardor, e de fé em si mesmas ocupam cada dia um lugar mais largo na vanguarda da civilização.

\section{Alteridades, familiaridades e estranhamentos}

A heterologia da viagem não diz respeito somente ao Outro pertencente ao out-group, mas também àquele oriundo do in-group, nascido no além-mar. A literatura de viagem analisada permite enumerar quatro alteridades distintas que, de certa forma, estão hierarquizadas segundo sua aproximação identitária com os viajantes: 1) a alteridade do próximo, ou seja, do teuto-brasileiro; 2) a alteridade dos demais europeus (geralmente, portugueses, ingleses e franceses); 3) a alteridade dos mestiços (no sul do Brasil, trata-se predominantemente do gaúcho); 4) a alteridade dos indígenas e africanos. 
Narrativas sobre o Brasil alemão ou a Alemanha brasileira...

\section{Alteridade do próximo}

Sobre o teuto-brasileiro, há uma certa perplexidade, pois ele causa uma impressão às vezes ambígua aos viajantes alemães. $\mathrm{O}$ teuto-brasileiro é considerado um igual, um Mesmo que nós, mas, em alguns casos, já não é mais o Mesmo. Trata-se de um semelhante, de um próximo, pois ora é estranho. A heterologia do teutobrasileiro é, em grande parte, uma homologia da viagem. Alter ego dos viajantes e dos seus leitores alemães.

Se, ao contrário de Ulisses, os viajantes alemães não buscavam o familiar e sim o exótico, acabaram se deparando com o familiar, notadamente nas colônias. Paradoxalmente, o familiar não era tão heimlich assim devido a uma bybris genealógica da cultura colonial. As colônias alemãs no Sul do Brasil apresentavam elementos novos que foram registrados com certa admiração por parte dos viajantes. Entre eles, destaca-se a nova geração já nascida em solo americano e que - apesar de falar alemão e preservar os costumes dos pais - apresenta características particulares.

Os filhos nascidos nessa terra livre, já casados e abençoados com rebentos, são a base e fundamento da colônia; e tão livres, tão sensatos, tão engenhosos e todavia tão vivos, tão livres, e tão audazes são eles que a gente realmente se admira e não compreende como os filhos e filhas de antigos jornaleiros e peões da Alemanha se acham tão magnificamente desenvolvidos no corpo e na alma, tais como fenômenos da natureza, não são selvagens e desenfreados, mas domados, contidos, conduzidos pela disciplina e pelos costumes, pelo lar, pela família, e pelo cristianismo. (Avé-Lallemant, 1980, p.155).

Os viajantes alemães viram o teuto-brasileiro como um Siegfried das florestas. Sua diferença não era física, já que nas colônias alemãs predominava, no século XIX, uma endogamia em ter-

Anos 90, Porto Alegre, v. 12, n. 21/22, p.227-269, jan./dez. 2005 
mos étnicos. Sua diferença estava no seu comportamento cultural, visto com certo romantismo pelo olhar dos viajantes alemães. Sobre os jovens de origem alemã, Avé-Lallemant (1980, p.185) pinta um retrato eugênico:

A segunda geração nascida em clima feliz, geração mais genial, diria eu, de homens jovens, vivos, independentes, de moças esbeltas, cheias de vida, conscientes de si mesmas, como os vi em São Leopoldo. Lá se tornaram mais nobres e melhores do que seus pais, desalentados, na pátria, com o fardo do trabalho infrutífero e dos preconceitos. Livres no solo livre dos pais. E isso também se manifesta no seu proceder, no porte, no movimento, no vestuário; tudo que fazem expressa decisão, segurança e certa flexibilidade que de algum modo já se poderia chamar educação, mesmo sem nenhuma verdadeira cultura escolar.

É também Avé-Lallemant (ibid., p.248) quem encontra um jovem alemão outsider a quem denomina de "índio alemão." Com espanto, havia ele encontrado um compatriota entre os bugres e que não falava mais uma palavra da língua alemã.

Sentamo-nos em bancos diante da porta. Julgava achar-me num mundo autenticamente americano, de pureza ainda não vista, e num ambiente em que nada mais me recordava a Europa. Só um rosto me parecia estranho na roda dos pardos, ou melhor facilmente reconhecível entre os estranhos filhos do Uruguai - mais um alemão que se achava entre nós. Naturalmente já quase nada sabia de alemão, pois chegara aos três anos de idade a São Leopoldo e pouco depois viera dali para as Missões, onde se tornara um verdadeiro índio alemão, um guarani de cabelos louros.

No caso desses jovens (teuto-brasileiros, índio-alemão), a retórica da alteridade não deixa de fazer uma incursão pelo Mesmo no que ele tem de Outro. Trata-se ao mesmo tempo de uma 
Narrativas sobre o Brasil alemão ou a Alemanha brasileira...

homologia da alteridade e de uma heterologia do Eu/Nós. AvéLallemant (ibid., p.123) viu na Serra de Hamburgo "o elemento alemão em toda a sua pureza". Esse contraste entre a Physis (americana) e a Kultur (alemã) não escapou aos olhos nem aos ouvidos de Avé-Lallemant (ibid., p.118):

Com as pastagens se alternavam plantações de milho, mandioca, feijão etc. De quando em quando se passa pela casa de um colono e se percebe com agrado entre os remanescentes da floresta virgem brasileira, a voz de uma população alemã incipiente e um bem soante "Schönen guten Tag"!

Em outra passagem, Avé-Lallemant (ibid., p.173) comenta sobre duas sonoridades que traduzem sua visão dicotômica entre natureza e civilização.

Nas matas americanas, conheço duas vozes de animais que são características e assim precisamente me pareceram em Fachinal. Cruel sempre me parece o guincho dos macacos: é o guincho do estado selvagem primitivo, da brutalidade e do desespero; não posso ouvi-lo sem sentir uma espécie de espanto.

O canto do galo, ao contrário, não é a trombeta da civilização que se aproxima? Apenas se abre uma clareira, apenas se edifica uma cabana, lá está o galo doméstico, dentro das brenhas, soltando a plenos pulmões o seu canto apostolar.

Assim como o canto do galo lhe aprazia também por ser familiar, a língua alemã aparece, várias vezes na sua narrativa, como um repère sentimental (ibid., p.125):

E como alegremente pula o coração do viajante alemão quando, percorrendo a serra por milhas e milhas, ouve de jovens e velhos, de homens e mulheres, a hospitaleira senha "Guten Morgen"! 
Além da ilusão nostálgica de volver ao home sweet home, temse o estranhamento do familiar que acusa a formação de uma nova etnicidade alemã no Novo Mundo. Isso não significava a superação de fronteiras étnicas. Ao comentar o futuro do Rio Grande do Sul, quando "uma nova geração, que só conhece a Europa de nome, que está habituada aos usos, costumes e modo de vida do país e não tem noção da existência de grandes comodidades, de outras alegrias, tomar o lugar da antiga geração", Friedrich von Weech (1992, p.186) faz alusão à permanência da língua alemã entre essa mesma nova geração:

E quando, em vez do cardo espinhoso, produtos agrícolas cobrirem as planícies e, quando, onde os olhos procurarem inutilmente por uma cabana ou uma árvore, existirem agradáveis habitações, rodeadas de árvores frutíferas e de cercas sempre verdes, e uma honesta saudação alemã convidar o passante a ficar $[\ldots]$.

Nota-se que Weech previa uma nova paisagem cultural com a expansão colonial em direção às planícies. Como sua experiência de viagem foi na vizinha Cisplatina, provavelmente o viajante alemão não tinha muitas informações sobre a região florestal destinada à colonização alemã que prosseguiu com outros imigrantes europeus para o interior das florestas da Serra Geral. Mas AvéLallemant, que viajou pelo interior do Rio Grande do Sul, conheceu suas florestas e testemunhou queimadas e derrubadas, e sinalizou para uma expansão colonial em direção à metade sul. Mas o viajante alemão não percebeu que o planejamento, a gestão e o ordenamento territorial que o governo operava vinha ao encontro dos interesses de uma elite agrária e que, por conseguinte, resguardava o latifúndio da imigração e da "enxamagem colonial". Aos colonos, sempre as áreas desvalorizadas pela pecuária extensiva, ou seja, as áreas montanhosas e de florestas. 
Narrativas sobre o Brasil alemão ou a Alemanha brasileira...

$\mathrm{Na}$ fase pioneira da imigração alemã, a densa floresta condicionou, junto com o contato raro e esporádico com os outros grupos, a formação de uma etnicidade alemã. Como forma de interação social, a etnicidade se manifesta em espaços sociais nos quais a tensão entre etnicidade e alteridade pode variar.

Enquanto tipo de organização social, a etnicidade é um processo contínuo de dicotomização entre Nós e Eles, e requer sempre expressão e validade na interação social. Tucídides já se referia à interdependência da classificação binária, antagônica entre os gregos e os bárbaros (Hartog, 2004, p.94). Interdependência que se faz igualmente presente na construção identitária de nativos e adventícios na Província do Rio Grande do Sul.

No caso dos imigrantes alemães, tem-se uma identidade dinâmica e cuja vitalidade não repousa num suposto apanágio cultural de um grupo étnico, tal como Deutschtum ou Volkstum, mas nas suas fronteiras manipuláveis pelos atores por meio de separações e diferenças com relação aos outros. Por isso, a identidade étnica só faz sentido com referência a uma alteridade.

Mas além da dimensão espacial, as relações interétnicas, que condicionam a etnicidade, têm igualmente uma dimensão temporal. Assim, o que diferencia, em última instância, a identidade étnica de outras formas de identidade coletiva é o fato de ela ser orientada para o passado. Para Max Weber (1972, p.237),

Grupos étnicos são aqueles grupos que nutrem uma crença subjetiva em uma comunidade de origem fundada nas semelhanças de aparência externa e/ou dos costumes e/ou nas lembranças da colonização ou da migração, de modo que essa crença torna-se importante para a propagação da comunidade, independente se seus laços sanguíneos existem objetivamente ou não.

Se a identidade étnica tem uma referência fundamental ao passado, sua instrumentalização foi, em grande parte, orientada

Anos 90, Porto Alegre, v. 12, n. 21/22, p.227-269, jan./dez. 2005 
para o futuro. A questão do aproveitamento dos imigrantes alemães foi tratada por viajantes em prol de uma Alemanha expandida, senão em seus limites geográficos, ao menos etnográficos. Os viajantes alemães contribuíram para ressaltar as vantagens de uma Deutschtumspflege in Ausland, mesmo que sempre tivessem o cuidado de advertir para a sua posição a princípio contrária à emigração. Como escreveu Weech (1992, p.183), "longe de mim encorajar a isso meus compatriotas." Beschoren (1989, p.29) também advertiu: "Não estou pensando em fundar colônias, Deus guarde!!!!”.

Para além das fronteiras políticas da Alemanha, imigrantes alemães se acomodaram numa nova geografia, onde reproduziram um modus vivendi capaz de dar aos viajantes uma impressão ambígua, ao mesmo tempo familiar e estranha. Mas como demonstrou Freud, o estranho pode ter sido familiar mas, posteriormente, reprimido.

\section{Alteridades européias}

Sobre os demais europeus no Brasil meridional, a narrativa dos viajantes alemães não diverge do consensual na Alemanha à época, especialmente em relação aos franceses, ingleses e portugueses. Uma particularidade dos encontros entre viajantes alemães e demais europeus deve ser aqui apontada para que a visão quase sempre simpática dos primeiros sobre os segundos seja considerada com certo relativismo. Os viajantes se hospedaram, geralmente, sob o teto daqueles europeus que foram descritos em seus relatos.

Segundo os viajantes, a hospitalidade praticada em toda a Província de São Pedro do Rio Grande do Sul era altamente valorizada pelos habitantes, independentemente de suas origens. Esse código de honra implicava em uma reciprocidade tácita. Frente à 
Narrativas sobre o Brasil alemão ou a Alemanha brasileira...

hospitalidade (de europeus ou não), o viajante registrava, em seu diário, elogios ao seu hospedeiro, destacando em geral aquilo que era valorizado na Província, como a hospitalidade "gratuita", e aquilo que os próprios viajantes estimavam, ou seja, um pouco de familiaridade, mesmo que efêmera. Como os viajantes recebiam cartas de recomendação, uma certa "rede hospedeira" na Província, composta principalmente por estancieiros luso-brasileiros e europeus, estes últimos quase sempre residentes nas cidades, era acionada em função de um viajante.

Essas cartas de recomendação abriam as portas de hospedagem aos seus portadores, mas também serviam para reforçar os laços sociais entre os autores das cartas e seus destinatários. Trocas de favores, sinais de reconhecimento e prestígio social e exibição de suas relações sociais podiam ser desencadeadas por uma simples hospedagem a um viajante eminente. Assim, viajantes alemães usaram e foram usados em redes sociais na Província, de que muitos outros europeus faziam parte.

Devido a um ethos da hospitalidade, as impressões dos viajantes abrigados em casa de europeus podem ter sido tolhidas no que tange à alteridade européia no Sul do Brasil. Concorrem também os seguintes aspectos para uma retórica da alteridade européia quase laudatória: eventual solidariedade entre estrangeiros, reminiscências comuns e a excepcional ocasião para falar mal de terceiros (os brasileiros).

Como a retórica da alteridade provoca, em geral, a exclusão de terceiros, pode-se inferir que na narrativa dos viajantes alemães sobre o outro, sua heterologia dos europeus se tornou homologia. Como observou Hartog (1999, p.270-271), parece que, em seu movimento para traduzir o outro, a narrativa mostra-se enfim incapaz de abordar mais que dois termos de cada vez. A retórica da alteridade tende, pois, a ser dual. Desse modo, frente às demais alteridades, mais contrastantes como a do indígena ou a do gaúcho, os alemães acabam por igualar a alteridade de france-

Anos 90, Porto Alegre, v. 12, n. 21/22, p.227-269, jan./dez. 2005 
ses, suíços e ingleses, tornando-os simplesmente Europeus, tal como os narradores e os seus leitores.

\section{Alteridades mestiças}

O olhar dos viajantes sobre a alteridade mestiça no Sul do Brasil sofre a influência da lente eurocêntrica. A partir dela, o gaúcho é visto de forma mais positiva do que o mulato ou o caboclo. Sobre os gaúchos, escreveu Beschoren (1986, p.101):

Essas pessoas, selvagens e ousadas, cuja pigmentação da pele varia numa escala de cores, desde o preto, mulato, até o branco, apesar da aparência perigosa, são sujeitos amáveis e não são tão maus como aparentam.

Avé-Lallemant (1980, p.375) corrobora a poligenia étnica do gaúcho, observada por Beschoren, e destaca ainda a possibilidade de interação do estrangeiro com os gaúchos, desde, é claro, que o primeiro saiba se comunicar na língua do país:

É difícil descrevê-los pela constituição física, pois são de variadas origens e em geral procedem das três raças, negra, índia e européia. Em minha peregrinação estive em contato com todos esses elementos e entendi-me perfeitamente com todos eles.

Já o mulato e/ou o caboclo despertam mais a desconfiança do que o interesse dos viajantes. Beschoren (1986, p.122) relata sobre um informante caboclo que "não inspirava confiança". Se os viajantes alemães acreditavam que a Geistzeit abençoara as Américas, não seriam suas hordas de mestiços sujeitos históricos capazes de qualquer missão civilizadora. Eles poderiam concordar parcialmente com as afirmações ufanistas do antropólogo Darcy 
Narrativas sobre o Brasil alemão ou a Alemanha brasileira...

Ribeiro (1997, p.265) de que o Brasil é uma "província da civilização ocidental", uma "Roma tardia". Porém, isso só teria sentido, segundo os viajantes, pela imigração alemã. A propos, AvéLallemant (1980, p.141-142) recorreu ao dito latino Tantae molis erat Romanam condere gentem para elogiar o progresso da colônia alemã de São Leopoldo.

\section{Alteridades indígena e africana}

Os indígenas e os africanos foram vistos como "empecilhos" ao curso da história em solo americano. Por ser uma história eurocêntrica em expansão, essas alteridades "frias" - para empregar o paradigma de Lévi-Strauss - eram quase incompatíveis com as "quentes" vindas do além-mar.

Civilizar-se era um imperativo. Beschoren (1986, p.63) faz uma distinção entre os Coroados: "Os civilizados não mantêm um bom relacionamento com seus irmãos selvagens." Apesar dessa distinção do outgroup, o viajante alemão reduz a alteridade indígena a uma substância ontológica.

Mesmo que se negue tudo sobre a origem do índio, vestindo-o adequadamente, cortando-lhe o cabelo comprido e desordenado, ensinando-lhe a falar o português, desenvolvendo uma determinada educação, mesmo com essa transformação, reconhecer-se-á nele, imediatamente, pelo olhar, o selvagem.

O olhar fixo, penetrante, que em nenhum ponto se apega, tem algo de sinistro. Grande deve ser a agitação interior, transmitida pelo brilho desconfiado de seus olhos. (Beschoren, 1986, p.65).

A forma de ver do Outro acusa seu próprio ser. Mesmo que Beschoren estivesse cônscio da mudança de comportamento dos indígenas na presença de estranhos, relatada inclusive em outras

Anos 90, Porto Alegre, v. 12, n. 21/22, p.227-269, jan./dez. 2005 
passagens da narrativa, ele não atentou para o efeito do cruzamento de olhares e mesmo para sua interdependência. Apesar das poucas linhas dedicadas a essas alteridades, os viajantes alemães foram cegados por preconceitos. Aqui, o encobrimento do outro acusa uma brecha da theoría, pois se pode viajar sem lograr mesuras.

Para mesurar com precisão é preciso ajustar o olhar. Beschoren (ibid., p.62) comentou que "viajando-se por essas terras, logo perde-se a mania alemã de julgar a fortuna das pessoas pela aparência e conforto como vivem". Se Beschoren logra ajustar

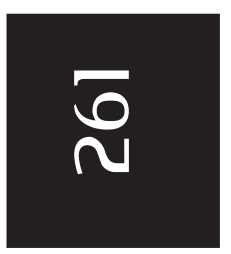
seu olhar durante a viagem, não faz o mesmo com o falar. Dos índios, o viajante alemão reclamou: "Essa gente não é de muitos amigos e nem conversas. Diante dos estranhos permanecem calados, e, se preciso, dão no máximo uma breve e exata resposta." (ibid., p.63).

Também Avé-Lallemant (1980, p.169) reclamou do comportamento taciturno indígena, a partir do qual julgou toda a aldeia como "um estabelecimento para esses retardados, onde lentamente, preguiçosamente vegetam sua vida de lêmures sem nada fazer, nada pensar, nada sentir!". Para o viajante alemão (ibid., p.168), a dificuldade em falar dos indígenas era um sinal de sua inferioridade em termos ontológicos.

Ao visitar a aldeia de São Nicolau, encontrei na praça em frente da capela um silêncio verdadeiramente tumular. Chegando a um casebre, apareceu-me uma jovem índia de rosto amável, meio idiota, e sua mãe, uma miserável virago. Afora algumas engroladas palavras portuguesas e um acanhado sorriso, que me pareceu realmente doloroso, nada mais pôde expressar a pobre mulher. Nem sequer me soube dizer se vivia muita gente na aldeia.

Mais adiante (idem), o viajante alemão encontrou outras mulheres indígenas, e novamente frustrou-se. "Queria falar-lhe, mas repetiu-se a mesma cena; os esquisitos fantasmas das brenhas não conheciam nada, nem sabiam, nem desejavam, nem diziam." 
Narrativas sobre o Brasil alemão ou a Alemanha brasileira...

Às margens do Uruguai, Avé-Lallemant (1980, p.274) discorre sobre esses "chineses do Oeste, de cujo perecimento como povo crepuscular ocidental já não se duvida." No sentido de LeviStrauss, a comunidade guarani seria, para o viajante alemão, uma daquelas sociedades "frias". Já sobre duas índias "mais ou menos charruas puras", Avé-Lallemant (ibid., p.285) comentou que elas tinham o rosto distinto das mulheres guaranis e "olhavam com mais audácia e liberdade do que suas compatriotas do norte". Diferenças físicas da alteridade indígena foram percebidas pelo olhar do viajante alemão, que também distinguiu diferenças internas do outgroup por meio do olhar do Outro. Mais uma vez, a forma de ver do Outro acusa o seu próprio ser. Apesar dos diferentes grupos étnicos, a dicotomia entre bárbaros selvagens e civilizados prevaleceu no olhar dos viajantes ao esquadrinhar a alteridade indígena.

Curiosamente, foi o próprio Avé-Lallemant (ibid., p.273) que se considerou um bárbaro quando, em casa do francês Jean Pierre Gay, em São Borja, lhe foram declamados versos em língua guarani. Barbarus hic ego sum, escreveu ele. Esse "estranhamento de si" do viajante alemão poderia aludir o filósofo cínico Diógenes de Sínope que, fazendo o elogio da vida selvagem, visava uma inversão da relação entre um centro grego e seus confins bárbaros (Hartog, 2004, p.21). Porém, percebe-se que a visão sobre a alteridade indígena oscila conforme o atendimento às expectativas subjetivas do próprio viajante. Onde ele foi bem acolhido e seus interesses atendidos de forma satisfatória, seu olhar tende a ser benevolente, mesmo romântico. Porém, onde prova de um tratamento inóspito e frustram-lhe os interesses, então, suas considerações são sempre desabonadoras.

Além de uma subjetividade muito sensível às adversidades situacionais, a autopsia de Avé-Lallemant (1980, p. 274) das alteridades no Brasil tem influência de sua formação médica, observável em sua teoria racial.

Anos 90, Porto Alegre, v. 12, n. 21/22, p.227-269, jan./dez. 2005 
Relativamente às diferentes raças que vi no solo brasileiro, tenho de dar ao índio o nome e os atributos de homemdo-ventre, para atribuir ao negro todas as qualidades somáticas e sentimentais do homem-do-peito, sobre os quais coloco depois o europeu e seus descendentes como homem-da-cabeça: divisão dos papéis que desempenham excelentemente no palco da vida. Isso não é simples figura de expressão, mas significativa verdade vital.

Dos viajantes alemães que servem de guias a essa viagem

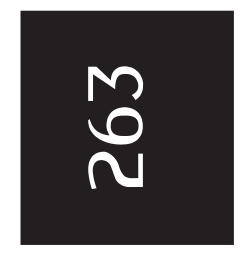
pela etnicidade e alteridade no Brasil meridional, Beschoren (1986, p.64) foi o que mais conviveu com os indígenas. Apesar do seu método de observação participativa, restaram alguns preconceitos que comprometeram a sua observação.

Durante dois meses realizei medições na região. Na oportunidade encontrava-me seguidamente com índios, espalhados na floresta, colhendo ervas. Encontrava-os no trabalho, na caça, nos seus fandangos e festas principais, podendo observa-los. Gostavam da cachaça, podendo-se transformá-los facilmente em amigos, se os presenteasse com algumas garrafas.

Ainda sobre o seu método de observação etnográfica, Beschoren (idem) destaca a necessária superação da desconfiança alheia pelo que ele denominou via diplomática.

Uma característica dos selvagens é a desconfiança com os estranhos. Quando se quer saber alguma coisa sobre hábitos, passado, pareceres religiosos, etc tem que se agir com muita diplomacia.

Esse seu método não está ancorado apenas em experiências de terceiros, como a do vigário ofendido pelos indígenas que interpretaram sua curiosidade como espionagem, mas também na sua própria experiência. Como Beschoren (1986, p.64) relata:

Anos 90, Porto Alegre, v. 12, n. 21/22, p.227-269, jan./dez. 2005 
Narrativas sobre o Brasil alemão ou a Alemanha brasileira...

Eu queria completar o meu vocabulário indígena, adquirido em Nonoai. Perguntei a um índio, que falava bem o português, sobre palavras e pequenas frases de meu interesse. No início dizia prontamente. De repente me perguntou por que eu queria saber isso ou aquilo. Disse-lhe que gostaria de aprender a língua de seu povo.

Pensou um pouco na minha resposta, que de maneira alguma o convenceu. Quando prossegui com minhas perguntas, me disse simplesmente: - "Isso você não precisa saber!” E desapareceu mata a dentro.

Nota-se que o viajante alemão nutria, mais do que um interesse pelo Outro, um interesse por si mesmo. Beschoren queria apreender a língua indígena como fizera com a portuguesa, mas de forma alguma via no meio cultural indígena um ambiente possível para si mesmo. Por fim, Beschoren (1986, p.45) não logrou mesuras válidas sobre a alteridade indígena em sua viagem. "Os índios não são tão maus: a gente pode muito bem tratar com eles. Deve-se, contudo, ter cuidado com a traição e a perfídia, visíveis em seu olhar."

A retórica da alteridade indígena nas narrativas dos viajantes alemães permite inferir uma relação entre natureza e costumes que não deixa de revestir sua etnografia de um contorno filosófico. Ao tratar da etnografia dos gregos, Hartog (2004, p.116) demonstrou que, ao inventariar os gêneros de vida de alhures, ela não deixa de comparar o selvagem do civilizado e de enfrentar a reflexão sobre a partilha entre physis e nómos.

$\mathrm{Na}$ etnografia dos viajantes alemães, há uma clivagem entre os indígenas. Tem-se índios bons e maus. Hartog (ibid., p.119) lembra que o sábio alexandrino Eratóstenes criticava aquela bipartição entre gregos e bárbaros e defendia os critérios da virtude e da maldade como os únicos válidos para o gênero humano, pois, para ele, muitos gregos eram "maus" enquanto muitos bárbaros eram "bons". No olhar dos viajantes alemães, a divisão entre selvagem e civilizado permanece, e se acopla àquela entre bons e maus; afinal, para eles, um índio "bom" era, geralmente, aquele civilizado.

Anos 90, Porto Alegre, v. 12, n. 21/22, p.227-269, jan./dez. 2005 
Em relação ao negro, o viajante Friedrich von Weech dedicou algumas páginas do seu livro, pois quando escreveu não havia impedimento legal para aquisição de escravos por parte de colonos estrangeiros. Como o seu público leitor alvo era o imigrante alemão, o livro de Weech informa sobre a relação senhor e escravo no Brasil. Interessa dessas informações a visão que se faz dos negros escravos.

Entre eles, os de algumas nações são menos rudes, muitas vezes aprendem com facilidade e vontade; outros são iguais a bichos em todos os aspectos, vivendo como esses. Porém, todos, sem exceção, são indolentes e têm grande inclinação para o roubo e as bebidas alcoólicas. É necessário tempo para que paulatinamente se acostumem a trabalhos que exijam esforço ou raciocínio, pois sua aversão a qualquer ocupação séria e penosa, principalmente os homens, é espantosa. (Weech, 1992, p.95).

Da relação entre senhores e escravos no Brasil, Weech (ibid., p.96) adverte seus leitores:

A permanência numa região pouco povoada, muitas vezes no meio de uma enorme floresta virgem, é em si mesma triste, e o habitante solitário restringe-se à convivência com a natureza e seus negros. Vendo-se rodeado por criaturas que o olham de modo medroso e hostil, em cuja fisionomia se lêem apenas o desânimo e a relutância contra tudo o que empreendem [...].

Visão pouco diferente do negro tem Beschoren, que alforriou seu escravo "Sexta-feira" por recompensa pela sua lealdade e afeição. Se a alcunha do viajante alemão a seu "companheiro negro, de muitos anos" faz explícita alusão literária ao personagem de Daniel Defoe, acusa outrossim que tanto a personagem indígena quanto o indivíduo real africano ou afro-brasileiro tem em comum 
Narrativas sobre o Brasil alemão ou a Alemanha brasileira...

sua relação assimétrica com o branco civilizado, apesar de qualquer afeição recíproca ou não.

\section{Considerações finais}

Para os viajantes alemães, a colonização alemã plasmou na paisagem do Brasil meridional uma extensão da Vaterland. No exótico brasiliense eles encontraram a sua Heimat. E durante suas viagens pelo interior do Sul do Brasil, viram uma Alemanha no Brasil e tiveram uma sensação ambígua de algo estranho e familiar ao mesmo tempo.

As narrativas desses viajantes também imprimiram imagens na retina de seus leitores. Como guias turísticos, eles informaram sobre paisagens e gentes de alhures. Promoveram uma viagem do Brasil em que paradoxalmente se apresentava um Brasil alemão ou uma Alemanha brasileira. No que concerne ao teuto-brasileiro, os viajantes fizeram seus leitores alemães verem-se por meio de uma heterologia que, ao fim e ao cabo, mostrava que o próprio chega de alhures, o mesmo vem de longe.

Virtualmente, essas narrativas permitem aos seus leitores realizar suas próprias viagens por meio da leitura. François Hartog (2003, p.127), ao tratar do método de Fustel de Coulanges, fez sua a assertiva: ler é ver. E se quem escreve, lê duas vezes (quid scribit, bis legit), o historiador empreende uma viagem doublé ao escrever com base na literatura de viagens.

Vale lembrar que essa viagem não substitui o ver com os próprios olhos. A propósito, o sociólogo alemão Achim Schrader (1999) enfatizou o passeio enquanto método sociológico em sua aula magna intitulada Loas ao passeio. Para Schrader, o sociólogo pedestre deve reconhecer as fronteiras de um espaço social e conhecer bem os cinco "atributos do espaço" de Georg Simmel para poder ir "em busca da realidade". Em sua aula magna, despediu-se

Anos 90, Porto Alegre, v. 12, n. 21/22, p.227-269, jan./dez. 2005 
da academia alemã com uma frase de Platão, o viandante clássico tanto para Schrader como para Hartog (2004, p.20). A frase foi aquela dirigida a Sócrates: I $\omega \mu \varepsilon v$ !

Ver com os próprios olhos, a exemplo de Políbio e tantos outros historiadores de antanho, e ir ao encontro do desconhecido, do exótico, mesmo que inusitadamente o estranhamento revele algo de familiar reprimido, foi o que fizeram os viajantes alemães "em busca de uma realidade". Suas narrativas sobre etnicidade alemã e alteridade no Sul do Brasil permitem ao historiador de hoje (mormente de pantufas como Timeu e Handelmann) reconstruir uma hetero/homologia que comprova o quanto viajar é uma experiência cognitiva ímpar.

Narratives on German Brazil or Brazilian Germany: etnhicity and alterity through journey literature

Abstract. This article aims at intertextual readings about ethnicity and alterity in southern Brazil through the books of three German travelers, archetypes of "manborder". This literature was interpreted as speech operators and narrative scheme. This historical analysis is concerned with travel as cognitive experience for a Heterology as well as a "German" ethnicity in German Brazil or Brazilian Germany.

Keywords: Ethnicity. Alterity. Heterology. Bordlines.

\section{Notas}

${ }^{1} \mathrm{O}$ emprego do termo "homens-fronteira" remete à sugestiva denominação do historiador francês François Hartog (2004).

${ }^{2}$ Entende-se aqui paisagem cultural como a tradução literal do conceito kulturelle Landschaft, de Leo Weibel.

\section{Referências}

AVÉ-LALLEMANT, R. Viagem pela Província do Rio Grande do Sul (1858). Belo Horizonte; São Paulo: Itatiaia; Ed. da Universidade de São Paulo, 1980.

BESCHOREN, M. Impressões de viagem na Província do Rio Grande do Sul (18751887). Porto Alegre: Martins Livreiro,1989.

Anos 90, Porto Alegre, v. 12, n. 21/22, p.227-269, jan./dez. 2005

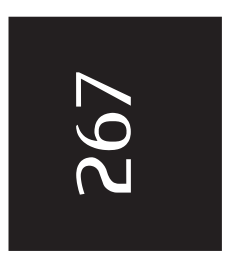


Narrativas sobre o Brasil alemão ou a Alemanha brasileira...

BORNHEIM, G. Introdução à leitura de Winckelmann. In: WINCKELMANN, J. J. Reflexões sobre a arte antiga. Porto Alegre: Movimento, 1975.

COULANGES, F. de. A cidade antiga. São Paulo: Hemus, 1975.

DRUMMOND, L. Ethnicity, "ethnicity" and culture theory. Man, v.16, n.4, p.693696, 1981.

FREUD, S. Das Unheimliche. In: . Studienausgabe. Frankfurt: Fischer Verlag, 2000. p.241-274.

HANDELMANN, H. História do Brasil. Belo Horizonte: Itatiaia, 1982 [1860]. v. 2.

HARTOG, F. O espelho de Heródoto; ensaio sobre a representação do outro. Belo Horizonte: Editora da UFMG, 1999. Memória de Ulisses; narrativas sobre a fronteira na Grécia antiga. Belo Horizonte: Editora UFMG, 2004.

O século XIX e a história; o caso Fustel de Coulanges. Rio de Janeiro: Editora UFRJ, 2003.

LEITE, M. M. Livros de viagem. Rio de Janeiro: Ed. UFRJ, 1997.

LEVINAS, E. L'bumanisme de l'autre homme. Paris: Fata Morgana, 1972.

LIMA, O. Prefácio a Heinrich Schüler. In: SCHÜLER, Heinrich. Brasilien; Ein land des Zukumft. Stuttgart; Leipzig, 1912.

MOMigliAnO, A. Atene nel III secolo A. C. e la scorpeta di Roma nelle Storie di Timeo di Tauromenio. Roma, 1966.

Os limites da helenização. Rio de Janeiro: Zahar, 1991.

- As raízes clássicas da historiografia moderna. Bauru, SP: EDUSC, 2004.

Sesto contributo alla storia degli studi classici e del mondo antigo. Roma, 1980. p.513.

PICCOLO, H. Rio Grande do Sul, século XIX: a imigração alemã e o processo de construção de identidades. A questão da nacionalidade. In: CONGRESSO EUROPEU DE LATINOAMERICANISTAS, 11, Halle, 1999. Actas del $11^{\circ}$ Congresso Europeu de Latinoamericanistas. Halle: Martin Luther Universität, 1999.

POUTIGNAT, P.; STREIFF-FENART, J. Teorias da Etnicidade. [seguido de Grupos Étnicos e suas Fronteiras de Fredrik Barth]. São Paulo: UNESP, 1998.

Anos 90, Porto Alegre, v. 12, n. 21/22, p.227-269, jan./dez. 2005 


\section{Sílvio Marcus de Souza Correa}

REDFIELD, J. Herodotus the tourist. Classical Philology, Chicago, n. 80, 1985.

RIBEIRO, D. Opovo brasileiro; a formação e o sentido do Brasil. São Paulo: Cia das Letras, 1997.

SALGUEIRO, V. Grand Tour: uma contribuição à história do viajar por prazer e por amor à cultura. Revista Brasileira de História, São Paulo, v.22, p.289-310, 2002.

SCHRADER, A. Loas ao passeio: um método menosprezado na pesquisa social empírica. In: SCHARER, A. Métodos de pesquisa social empirica e indicadores sociais. Porto Alegre: Ed. da UFRGS, 1999.

TURNER, F. The frontier in American history. New York: Henry Holt and Company, 1921.

WALLERSTEIN, I. Ethnicity and national integration in West Africa. Cabier d'Études Africains, Paris, n.3, p.129-139, 1960.

WEBER, M. Wirtschaft und Gesellschaft. 5. ed. Tübingen, 1972.

WEECH, F. A agricultura e o comércio do Brasil no sistema colonial. São Paulo: Martins Fontes, 1992.

Recebido em 20/05/2005.

Aprovado em 02/08/2005. 